\section{The animal question: the Anthropocene's hidden foundational debate}

\section{La cuestión animal: el debate fundacional oculto del Antropoceno}

\author{
Abel A. Alves ${ }^{i}$ \\ 'Professor and Chairperson, Department of History/ \\ Ball State University. \\ Muncie - IN - USA \\ orcid.org/0000-0002-7244-4116 \\ aalves@bsu.edu
}

ALVES, Abel A. The animal question: the Anthropocene's hidden foundational debate. História, Ciências, SaúdeManguinhos, Rio de Janeiro, v.28, supl., dez. 2021, p.123-140.

\section{Abstract}

As globalization accelerated after 1492, often in the service of European imperial expansion, human destruction of the habitat in which animals could express their natural behaviors also increased. Within this context, the question arises: just how much are we like other animals, and if they are like us, how much do we owe them? From the 1500s to the 1800s, travelers, imperialists, the colonized, and intellectuals tried to answer this question and produced three positions: animals as mere exploitable devices; confusion about animals' status and what we owe them, and concern about the suffering of nonhuman animals, their freedom to express their behaviors, and their very existence.

Keyword: Anthropocene; animal studies; history; imperialism.

\section{Resumen}

A medida que la globalización aceleró después de 1492, generalmente en el servicio de la expansión imperial europea, también aumentó la destrucción humana del hábitat en el que los animales podían expresar sus comportamientos naturales. En este contexto, surgió la siguiente pregunta: ¿cuánto nos parecemos a los demás animales y, si ellos son como nosotros, cuánto les debemos? Desde 1500 hasta 1800 , viajeros, imperialistas, colonizados e intelectuales intentaron responder a esta pregunta y formularon tres posiciones: los animales como meros dispositivos explotables; confusión sobre el estado de los animales y lo que les debemos; y la preocupación por el sufrimiento de los animales no humanos, su libertad para expresar sus comportamientos y su propia existencia.

Palabras clave: Antropoceno; estudios con animales; historia; imperialismo. 
Animals offer companionship to lessen the solitude of the human species, but along with this companionship comes a living presence endowed with a pair of eyes that observes and takes notes.

Bénédicte Boisseron (2018, p.157)

As globalization accelerated after 1492, often in the service of European imperial expansion, human destruction of the natural world also intensified. However, a master narrative reducing this planet and its nonhuman animals to mere resources exploited for often transitory human desires confronted challenges from a different human perspective based on similitude and sympathy. These two positions at times were combined in the same individual, and were rooted in indigenous traditions around the globe, not just in the minds of European intellectuals and imperialists who might or might not consider themselves the world's sole agents. Globalization and imperialism could support an ecological narrative including kinship with other animals, while also laying the groundwork for the Anthropocene - an epoch not yet officially recognized, but characterized by human domination of the entire planet through technology and the potential extinction of many nonhuman species which were somehow deemed irrelevant or obtrusive.

During the development of the Anthropocene and its impact on nonhuman animals, European imperialism played a substantial role from 1492 to its political demise in the twentieth century. ${ }^{1}$ This imperialism led by two transglobal empires took early modern natural philosophy and nineteenth-century science beyond Europe, constituting the strands of a complex narrative. In 1492, the Columbian Exchange initially imposed by the Spanish empire led to an Atlantic world transfer of animals, plants, and microbes. Next, in the late eighteenth and early nineteenth centuries, the English empire and its Industrial Revolution began the process of mechanizing life itself. From Edward Jenner's smallpox vaccine to Alexander Fleming's penicillin, medical and scientific innovations in the British empire also helped reduce the death rate for humans; the human population first reached one billion people at the start of the nineteenth century and is now approaching eight billion in the early 2020s. Together, these empires began a process of redefining the planet and nature as something for humanity to manage. The Anthropocene emerged and consequently threatened the very existence of a large portion of nonhuman animal life. But even as nonhuman animals were increasingly reduced to utilizable resources, people expressed fascination and sympathy for them.

In 1996, the environmental historian Richard Grove recognized a "Green Imperialism" that could lead to either calls for sustainability, in order to avoid the utter depletion of "resources," or to a search for new "Edens" where a fallen humanity might be redeemed by what mercantilism and industrialization had not yet ruined. The French naturalist and novelist Jacques-Henri Bernardin de Saint-Pierre (1737-1814) was one of many Europeans who learned to appreciate a local environment and its fauna, developing an "awareness of the destruction of the endemic fauna and flora of Mauritius." This led him to write against deforestation on the French-controlled island, in Grove's (1995, p.248, 486) words recognizing "that the interdependence of one part of nature with another meant that destruction in 
one part would have deleterious consequences for the whole" (p.252). Later, in nineteenthcentury British Africa and India, a handful of desultory initial conservation efforts were made. In 1846, the Cape Colony attempted to protect the elephants of the Knysna Forest, and Calcutta Zoo superintendent Ram Brahma Sanyal (1858-1908) achieved some success in early breeding programs for lemurs, tigers, and leopards (Grove, 1995, p.465-466; Mittra, 1996, p.89). Still, this dialog and debate about our kinship with or dominance over other animals was not limited to Mauritius, India, southern Africa, France, and England: it was present in the earliest staging ground for modern European imperialism, the Atlantic world that embraced four continents, and continues today when individuals like Edward O. Wilson and Donna J. Haraway discuss the best way to ensure animal survival amid extinctions that are related to humanity's terrestrial footprint and conservatively estimated to exceed the normal background rate of species extinction by at least one hundred times ${ }^{2}$ (Venter et al., 2016; Lamkin, Miller, 2016; Wilson, 2016, p.54). The debate over our domination of other animals has involved women and men, individuals representing multiple ethnicities and cultures, local bureaucrats, and scholars and intellectuals. It also involves nonhuman animals, who through their observable behaviors and obvious sentience contradict the much-repeated Cartesian narrative that they are only stimulus-response machines, totally different from us and consequently subject to exploitation.

\section{The Atlantic world and nonhuman animals}

To succinctly capture the formation of the debate as it existed in early modern Europe, it is still useful to compare the thinking of René Descartes (1596-1650) with that of Michel de Montaigne (1533-1592). Not only did Descartes argue that nonhuman animals were mere unfeeling machines, he coldly described vivisection and cutting into a living dog's heart. Even though he reportedly expressed his affection for a pet dog named Monsieur Grat, his reduction of dogs and other animals to machines inspired his followers to use nonhuman animal blood in xenotransfusions and utilize vivisection to demonstrate human anatomy and physiology. At the very same time, these Cartesians argued that the animals howling during gruesome interventions did not experience pain comparable to humans (Sahlins, 2017, p.28-47). This sad irony was recognized and criticized by Voltaire in the eighteenth century, even as his sixteenth-century French intellectual predecessor Montaigne had argued prior to Descartes that animals were sentient agents. Montaigne wondered whether he played with his cat or if his cat played with him, and even though he hunted, he recognized animal suffering, admitting a certain level of discomfort at the squeals of a hare set upon by his hounds (Montaigne, 1991, p.505, 481). Voltaire, in turn, wrote that beasts could not be mere machines, noting that a lost dog will search the streets for its master with mournful cries, and that the mechanists who would nail a live dog to a table to show how veins work actually contradict their own claims that nonhuman animals do not feel when they cut into the same animal to make analogies with human anatomy and physiology, the mechanical engine of behavior. Voltaire aptly asked, "Answer me, mechanist, has Nature arranged all the springs of feeling in this animal so that he might not feel?" (Voltaire, 1765, p.44). 
The early modern French debate over the status of animals has been studied extensively, from George Boas's (1933) The happy beast in French thought of the seventeenth century to Peter Sahlins's 1668: the year of the animal in France, but this debate was not limited only to France. In Europe, Montaigne was joined by Spaniards who also sympathized with nonhuman animals, trying to ascertain their feelings and behaviors in order to better understand humanity, among other things. They included Oliva Sabuco de Nantes Barrera and Miguel de Cervantes, in the sixteenth century (Alves, 2011, p.34-63), and Benito Feijóo in the eighteenth. Feijóo, a clerical proponent of the Enlightenment in Spain, directly attacked Descartes and a sixteenth-century Spaniard named Gómez Pereira (who Descartes apparently read at some point) for portraying animals as mechanical automata that only move as iron is moved by a magnet. Feijóo argued that a cat will refrain from taking a piece of meat when observed and steal it when not being watched, and that dogs and cats will choose whether or not to fight (Alves, 2011, p.189-192). From Montaigne and Descartes to Feijóo, European intellectual attitudes toward nonhuman animals were conflicted and complex. They were also enhanced by the experiences of Europeans abroad who interacted with a new set of nonhuman animals, and with the indigenous peoples who first observed and analyzed these animals.

In the sixteenth century, Spanish bureaucrats in the Americas periodically wrote relaciones and even entire chronicles that approached history as both natural and cultural, broadly animal and human - very much in the tradition of Pliny the Elder in Greco-Roman times (Myers, 2007, p.88-90; Wagschal, 2018, p.121). Numerous ancient Mediterranean writings aside from Aesop's fables compared human and nonhuman animal behaviors, and Romans witnessing the death of elephants in their "games" even expressed sympathy on rare occasions (Kalof, 2007, p.31). As the Iberians (with their own bullfights) traveled across the Atlantic after 1492, they brought this complex of approaches with them, and were met by perspectives, attitudes, and animal behaviors that both complemented and challenged their own.

When Spanish bureaucrats such as Gaspar de Cobarrubias, Diego D'Esquibel, and the alcalde mayor of the fortress of Santo Domingo Gonzalo Fernández de Oviedo wrote about animals of the western hemisphere which were new to them (like the armadillo and opossum), they struggled to understand what they saw using categories from the eastern hemisphere. Consequently, the corregidor of Chinantla Diego D'Esquibel is just one example of many comparing the American armadillo to an armored European horse (Paso y Troncoso, 1905-1906, v.4, p.66). John Beusterien (2017, p.52) writes that this was done by many to promote "the idea that the European horse and its rider were superior to the marvelously strange, but smaller American horse." Indeed, Oviedo (1526, p.22a) directly compared armadillos to caparisoned horses, while also stressing that they were no bigger than "the size of a small dog."

Although resembling an armored horse, the armadillo ("little armored one") was small like a lapdog, supporting Beusterien's observation that the "American horse" was portrayed as inferior. American animals may have been fascinating, but were to be ranked according to their value in the eyes of Europeans. When the corregidor of Tuçantla Gaspar de Cobarrubias described the opossum, he did take the time to marvel at its being a marsupial, but also 
used Nahuatl (tlaquatl) to name it "tlaquaçint, which means 'one who eats much' ... it eats chickens" (Paso y Troncoso, 1905-1906, v.7, p.25-26). Unlike Cobarrubias, the indigenous Nahua interlocutors interviewed for the Franciscan Bernardino de Sahagún's Florentine Codex described a much less threatening animal: "It is quite harmless, not vicious; it does not bite, it does not nip one when it is taken, when it is seized. And when it is caught, it cries, it squeals; true tears come forth, especially when it is taken with its young" (Sahagún, 1981a, p.11-12).

The accumulated documentation for the early modern Spanish empire reveals a blend of curiosity, cold calculation, and sympathy in relation to nonhuman animals, and this crossed ethnic divides, with Nahuas obviously concerned about locusts that ate and destroyed whatever plants appealed to them, and with worms called cinocuilin that destroyed maize (Sahagún, 1981a, p.96, 99). Animals were threats, and they were eaten. They also could be cattle hides used in the manufacture of leather goods. In this way, the Jesuit José de Acosta (2002, p.231) noted that Spain imported 35,444 cattle hides from Santo Domingo in 1587 , while 64,350 hides worth 96,532 pesos were transported from New Spain. Animals were dangers, and they were resources. But the fact that they were also sentient agents could not be entirely denied, and Acosta (2002, p.241), in his Pliny-inspired Natural and moral history of the Indies, demonstrated a true appreciation for monkeys, noting that when trained, they acquire skills that "seem worthy of human intelligence rather than of brute animals." Sahagún, who together with his indigenous Nahua students collected accounts from Mesoamerican speakers of Nahuatl who had survived the collapse of the Mexica (Aztec) imperial hegemony, also recorded a sense of similitude with other living creatures that was present in indigenous cultural tradition and included monkeys:

It has human hands, human feet, nails, real nails - long nails. ... And all the maize, fruit, meat become its food; it eats like a human being. ... The monkey is a rather tame [animal] which sits like a man. Also it teases the young women; it begs from them, extends the hand, continually offers its hand in their presence (Sahagún, 1981a, p.14).

At the same time, the indigenous tradition of the Nahuas prior to Spanish intervention offered both humans and other animals to the deities. As in Europe, similitude and sympathy existed side-by-side with the use of animals, nonhuman and human alike. A quail might be "exceedingly good-tasting," two golden eagles might be buried at Tenochtitlan's Templo Mayor as offerings to the gods, and a human warrior might also be compared to an eagle when sacrificed, his heart ripped out by priests, while an opossum might be pitied (López Luján et al., 2014; Sahagún, 1981a, p.49, 1981b, p.48).

Elsewhere in the Atlantic world, from the Afro-Peruvian healer Martín de Porres (1579-1639) to the English intellectual Margaret Cavendish (1623-1673), there was also a recognition of and sympathy for animal suffering well before Jeremy Bentham (1780, p.309, note a) stated that the question central to our treatment of nonhuman animals was not whether animals reasoned, but whether they suffered. Like the indigenous Nahuas, Porres and Cavendish accepted that animals felt like us. Fray Martín, who was normally quite humble according to those who knew him, reprimanded a superior for putting a loyal but sickly kitchen dog to death. According to the seventeenth-century biography written 
by his fellow Dominican, Bernardo de Medina, Porres then raised this dog from the dead (Alves, 2011, p.177). Margaret Cavendish, the Duchess of Newcastle, not only sympathized with a poor rabbit she named Old Wat, which was taken by hunters and their dogs, she also portrayed nature in her poems as one vast interaction of cosmic sympathy, influenced as she was by the ancient Roman poet Lucretius (Cavendish, 2018, p.35, 163, 215). A future biracial Catholic saint and an English poet and atomist, Porres and Cavendish represented different paths to the same position: that humans shared something with other animals and should be concerned about the planet's other sentient beings. Descartes's voice was not the only one in the Atlantic imperial world, although his beast-machines may have increasingly served the objectives of those who would industrialize life itself in human slaves used as means of production on plantations, workers used as tools in industrial factories, and pigs confined to the Anthropocene's concentrated animal feeding operations.

Montaigne's similitude and sympathy was not his alone, and was occasionally even expressed amid the most abominable acts. While Spanish conquistadores taught their war dogs to maim and kill indigenous human victims in the Americas, accounts portray them mourning Becerillo, one of these dogs, with more sympathy than they showed the Amerindians they abused (Alves, 2011, p.155-156). Likewise, historian Marcy Norton has cited Gonzalo Fernández de Oviedo to demonstrate that hardened Spaniards could both kill and then regret killing three pigs that were the hunting companions of a Taino man who had escaped Spanish dominance by living in the wilderness (Norton, 2015, p.28-29). There certainly were instances of sympathy that crossed the species line during transatlantic imperial expansion, even as some imperialists showed a complete lack of feeling for their own species. Any animated life form, nonhuman or human, could be reduced to a resource to further territorial acquisition and the establishment of dominance. By extension, in the Spanish empire both feral animals and African slaves who escaped Spanish rule became wild and renegade, known as cimarrones (Alves, 2011, p.87-88).

Intellectual somersaults were often undertaken to dominate, hurt, and abuse other animate beings. Indigenous Americans and Africans were somehow "corrupted," "lesser humans," Aristotle's natural slaves, or people who had fallen under the spell of Satan and worshipped demons (Pagden, 1982, p.27-56, 175-176; Wimmler, 2015). Meanwhile, although republican, the Sephardic Dutch philosopher Spinoza (1632-1677) still exhibited human hierarchical preferences while admitting sentience in nonhuman animals. Indeed, he dismissed sentiments against killing animals as "empty superstition and unmanly compassion." Thus:

The rational principle of seeking our own advantage teaches us the necessity of joining with men, but not with the lower animals, or with things whose nature is different from human nature. We have the same right against them that they have against us. Indeed, because the right of each one is defined by his virtue, 'or' power, men have a far greater right against the lower animals than they have against men. Not that I deny that the lower animals have sensations. But I do deny that we are therefore not permitted to consider our own advantage, use them at our pleasure, and treat them as is most convenient for us. For they do not agree in nature with us, and their affects are different in nature from human affects (Spinoza, 1985, p.566; emphasis in the original). 
Although "beasts" may feel pain and are not Cartesian machines, they are competitors of a different nature from us, and we can dominate them. This, Spinoza's tacit definition of the Anthropocene as an epoch in which all nonhuman life is defined by its "use value" to whomever holds the power may be the most precise.

In the service of an imperial human, different levels of value might be attached to different animals. Men, dogs, and horses might all serve as cannon fodder, and still be admired for certain qualities or capacities - their agency never fully being denied. Bernal Díaz del Castillo (1632, p.16a), in his account of the Spanish invasion of sixteenth-century Mexico, took the time to write about the qualities of the horses involved, including one called "la Rabona," which he described as a very powerful and spirited runner. And Oviedo (1851, p.484-485), in describing the dog Becerrillo mentioned above, reported that the dog chose to urinate on an old indigenous woman who submitted to him and begged for mercy rather than maul her to death. The poor woman was thereby simultaneously subjected to a humiliating act of dominance and clemency by a dog, who was both tool of the conquistadores and an independent agent. Globalizing empires extant after 1492 continued to experience this sort of subjected nonhuman agency, even as they extended their imperium to other parts of the planet.

\section{Industrial mechanism and nonhuman animals}

With the end of the eighteenth century, an early modern first wave of European imperialism begun in 1492 was transformed, with artisanal production, mercantile activity, and cash crops produced on fazendas and haciendas increasingly modified by newer industrialized and steam-based means of production. Both nonhuman animals and humans continued to be resources and trophies. Thomas More (1964, p.24) reported that for the sake of woolen textiles, sheep were consuming people in sixteenth-century England, and by the nineteenth century the Cartesian machine was consuming people and the entire planet. In places like nineteenth-century Cuba, where slavery was practiced, some voices were raised in an attempt to limit abusive treatment of animals as well as human slaves, in an invidious comparison that showed how the Anthropocene's abuses of domination were not restricted to only oxen and other nonhuman animals (Funes Monzote, 2013). ${ }^{3}$ Agency and resistance remained, but were often met with an ideology combining dreams of imperial expansion with industrialized methods, reducing all organic life to extensions of the machines found in places like sugar mills and textile factories.

Again, the victory of Cartesian mechanism could never be universal, since it ignored human feelings that could not be denied. In the 1790s, as the Industrial Revolution was gaining speed in England, the French naturalist and director of the Jardin des Plantes Jacques-Henri Bernardin de Saint-Pierre argued that the animals in the royal menagerie at Versailles should be moved to the Parisian Jardin, where they could be seen by a cross section of the French estates, contributing to the edification of the people and providing live animals for observation by scholars and artists. At the height of the French Revolution, Bernardin de Saint-Pierre (who had returned to Paris from Mauritius) made special note of a Senegalese lion living with a canine companion. He observed that while the lion had wounded the dog in rough play, it had not killed the dog. The powerful and the masses 
could thus live in some sort of mutual arrangement, and Bernardin de Saint-Pierre's appeals saved the living luxuries of Versailles from the taxidermist, moving the animals from the king's palace to a more public venue, where the menagerie was transformed into the republic's zoo (Robbins, 2002, p.213-230). Still, this did not ultimately save the successors of Bernardin de Saint-Pierre's animals; during the Prussian siege of Paris (September 1870-January 1871) they were sold as exotic meat to the wealthy who could still afford it, while other Parisians went hungry (Spang, 1992, p.757). In desperate times, human elites reduced occasionally cherished animals to consumables.

Indeed, this conflicted view of nonhuman animals which was intertwined with imperial and class issues became a sometimes-ignored central theme of the nineteenth-century British empire - the industrial age's replacement for the early modern world's globalizing Spanish empire, which itself stretched from the Philippines in Asia through the Americas to Europe, and from 1580 to 1640 included Luanda, Goa, and other ports in Africa and Asia with the annexation of Portugal and its empire. Just like the Spanish empire before it, the globalizing British empire demonstrated curiosity about animals newly observed by Europeans, some sympathy for subordinated animals, and a willingness to reduce all animals (nonhuman and human alike) to the status of resources.

Shortly after returning from Asia in 1824, the imperial bureaucrat Sir Stamford Raffles (1781-1826) organized his friends and acquaintances among the British elite to found the Zoological Society of London, which led to the opening of the Gardens of the Zoological Society (today's London Zoo) in 1828. By 1829, the park's governing council announced that 112,226 individuals had visited the park in its first year. With King William IV's gift of the royal menagerie (which had been confined at the Tower of London) to comprise the park's initial collection, the royal collection was replaced by a more public zoo meant to educate, entertain, and display global dominion through exotic animals confined to small cages. This mission was preceded by local menageries in the United Kingdom, where for the price of admission the general public could see elephants and lions, even as Philip II had put an elephant and rhinoceros on public display in sixteenth-century Madrid (Ritvo, 1987, p.205-213; Cowie, 2014, p.12-30; Beusterien, 2020, p.77-78, 100). The common people of England could take vicarious pride in the imperial achievements of their "betters" around the globe, which included the domination of nonhuman animals. In her classic The animal estate, Harriet Ritvo (1987, p.247) writes, "At Entebbe, toward the end of the nineteenth century, British officials would accept young, healthy wild animals, which were valued at the rate of 3 rupees for a bush pig, 90 for a zebra, 300 for a hippopotamus, and 3,000 for an elephant, in lieu of taxes." The importance of imperial display is seen in the fact that conquered animals were "wanted dead or alive:" they were trophies. The ivory hunter and specimen collector Frederick Courteney Selous was lionized when he began lecturing in 1895 after some twenty years of hunting in southern Africa. Aside from what he sold during his lifetime, in 1919 his widow donated approximately five hundred specimens including "at least 19 lions, $18 \mathrm{kudu}, 11$ eland (kudu and eland were considered the noblest quarries among the African antelopes), and 10 rhinoceroses" to the British Museum (Natural History) (Ritvo, 1987, p.252). When brought back alive, the animals served an end that Ritvo (1987, p.232) has summarized nicely: 
Maintaining exotic animals in captivity was a compelling symbol of human power. Transporting them safely to England and figuring out how to keep them alive were triumphs of human skill and intelligence over the contrary dictates of nature. ... Most visitors to Victorian zoos, viewing the confined and uprooted creatures, were content to bask in this reflected glory.

Prior to the Victorian zoo, menageries were kept by potentates around the globe to display their dominion. In Ming China and Aztec Tenochtitlan, animals were collected to be seen by the emperor and, more importantly, the court and its visitors, displaying a power over the exotic, and over nature itself (Hoage, Roskell, Mansour, 1996, p.12-13). Tenochtitlan's menagerie even included humans with physical abnormalities (a "human zoo"), and Matthew Restall (2018, p.124-139) has proposed that the Aztec ruler Moctezuma wished to add Cortés and his Spanish compatriots to his collection to reassert a claim to "universal knowledge." In this way, the imperial dream was human, not just European, and sometimes Europeans in the early modern period expressed it poorly compared to their conspecifics in Asia and the Americas. John Beusterien (2020) describes Philip II's display of an elephant and rhinoceros at a Madrid hospital as an exhibit of power over a global empire to the masses of Madrid, not just to courtiers. This act blended the principles of the palace menagerie with the public zoo, but with two animals rather than a comprehensive display of Spanish dominance over animals from around the globe. The expansiveness seen in Moctezuma's collection returned in the nineteenth-century zoological park and its use of animals as imperial resources.

Just as Spaniards once defined their imperial dominion and ascendancy by reducing both slaves and nonhuman animals to the status of property, and as Moctezuma actually put humans on display, nineteenth-century zoos presented humans together with nonhuman animals. For over fifty years, starting in the mid-1870s with an exhibit of Sami people interacting with reindeer, the German zoo entrepreneur Carl Hagenbeck presented some seventy ethnographic performances at his Tierpark. He called these displays "anthropological-zoological exhibitions," and they were repeated by others, with an "Ashanti Show" in 1897 at the zoological gardens in Vienna, and the Mbuti Ota Benga was exhibited in a cage with chimpanzees and orangutans at the Bronx Zoo in 1906 (Reichenbach, 1996, p.55-56; Rothfels, 2002, p.82-83, 131; Oliveira, 2016, p.74-76). Like nonhumans, Mbuti, Ashanti, and Sami individuals were invidiously reduced to objects, to be dominated and displayed by conquerors of human culture and the natural world. Until recently, when zoos in London, England and Adelaide, Australia displayed individuals of European ancestrylike animals, this was a truly horrible practice that reduced conquered humans to animal status, while the conquering Europeans were exempted - just as Descartes reduced nonhuman animals to machine status while his self-reflective humans (presumably European) were exempted (At London Zoo..., 28 Aug. 2005; Reuters Life, 21 Jan. 2007).

The practice of the "human zoo" does raise questions about our ability to critically reflect upon self-aggrandizing displays of dominance. Still, reflection did occur; even as industrialization and imperialism came to define nineteenth-century Britain, some Romantics raised their reflective challenges. Mary Shelley rebelled in writing against the efforts by European men to dominate nature in her two great early nineteenth-century 
novels, Frankenstein and The last man. In Frankenstein, the natural philosopher Victor Frankenstein conquers death without ever asking what life would be like for the cadaverous creature he reanimated. In The last man, humanity succumbs to a global pandemic that leaves room for nonhuman animals and the vastness of living nature to thrive, even as her heartless, economy-driven Europeans first ignore the plague since it has not affected them, "only" menacing "(t)he vast cities of America, the fertile plains of Hindostan, the crowded abodes of the Chinese... with utter ruin"(Shelley, 1994, p.233, 276; Murphy, 4 May 2020). With her husband Percy Bysshe Shelley, a promoter and practitioner of vegetarianism who saw the path to human liberation as immersion in nature, Mary Shelley also made Frankenstein's monstrous creature a vegetarian by choice. The creature tries meat, only to return to berries, nuts, and roots. In fact, when the monster begs his creator for a bride, he promises they will live in peace, away from humanity, and only eat plants and fruit (Shelley, 2012, p.72, 102-103; Adams, 2015, p.69-72, 90-93, 95-107). Rather than striving for dominance over sentient life and nature, Mary Shelley wanted her readers to envision a world where humans peacefully accepted their place in nature. Still, this dream may have been unattainable for her, as indicated by the extermination of humanity and ultimate triumph of nature through a plague in The last man.

More hope could be glimpsed in the fiction of Anna Sewell and the political and social victories of Richard Martin and England's Society for the Prevention of Cruelty to Animals. In 1822, a bill sponsored by Martin and endorsed by clergy and London magistrates was passed by both houses of British Parliament. The bill prevented improper treatment of cattle, and was extended in 1835 to include pets and ban the popular activities of bullbaiting and cockfighting (Ritvo, 1987, p.127-128). In doing so, Britain achieved a goal expressed during the eighteenth-century Spanish empire; the Bourbon dynasty there had considered animal fighting and the bullfight itself as sources of unruly social behavior. Bullfights were banned for periods of time and in certain cities and regions, only to return as the "popular sport" of Spain in a nineteenth-century conservative reaction to the loss of most of Spain's empire and to the Enlightenment-inspired reforms of the Bourbons and Napoleonic occupation (Alves, 2011, p.195-198). In Britain, the local version of the bullfight (bull-baiting involving dogs) was banned, even as the foxhunt persisted. Just as the Spanish elite of the eighteenth century saw the bullfight as a locus of immoral and criminal behavior, the abuse of animals in Britain often came to be associated with the "depravity" of the lower classes. Anna Sewell (2016, p.143), a Quaker and the author of Black beauty, presented a notable exception with her character Jerry Barker, a cab driver who was kind to his horses and cared for them well. More typically, the Royal Society for the Prevention of Cruelty to Animals (founded in 1824 and granted royal status in 1840 by Queen Victoria) only made efforts "to suppress rather specialized elite abuses, such as cruelty to polo ponies or cropping the ears and docking the tails of show dogs" (Ritvo, 1987, p.134). Elite practices like the vivisections performed by scientists were not targeted as the cruelties of the "uneducated" in need of "discipline" were, and by 1875 separate antivivisectionist societies were founded in Britain (p.160-164). Mary Shelley's unfeeling, mechanical scientist even reappeared in fiction just over 75 years later as H.G. Wells's Doctor Moreau, the vivisectionist creator of human-animal hybrids (Lansbury, 1985, p.150-151). 
The industrial world of second-wave imperialism continued a debate from the early modern Atlantic world: were nonhuman animals sentient agents, or merely stimulusresponse machines? Utilitarian philosopher Jeremy Bentham succinctly reduced the discussion to an almost Buddhist sensibility that human and nonhuman animals alike are capable of experiencing suffering. Like Spinoza, Bentham still allowed for human dominance of nonhuman animals, without untoward cruelty, in order to achieve the "greatest good" for the greatest number of humans, but the door was left open to construct a more caring and feeling imperial science. Others in the British empire besides Mary Shelley and Anna Sewell wished to see power (and the pursuit of knowledge used to acquire power) tempered with care, concern, and what Margaret Cavendish, like Lucretius and Montaigne, would have seen as cosmic sympathy. From Charles Darwin and Alfred Russel Wallace, the co-discoverers of the theory of evolution by means of natural selection, to Calcutta Zoo superintendent Ram Brahma Sanyal and the feminists and workers who united in their opposition to the vivisection of a brown dog, the opponents of reducing sentient nonhuman animal life to a mere mechanism represented the ironic diversity of empire itself, just as the earlier Spanish empire saw animal sentience and welfare defended by a biracial saintly brother and healer like Martín de Porres and an elite priest like Benito Feijóo. The question always remains as to whether an empire can remain together, embodying its dreams of unification, or whether contentious fragmentation and disintegration are inevitable.

Before full-fledged industrialization in the early modern period, from 1492 to 1789 , Montaigne's alternative to Descartes was not his alone, nor was it only developed as a set of human ideals and projections; it was based on proto-ethology, a willingness to at least try to observe the behavior of other animals, and on the conclusion that if they behave like us, they are like us, and we are like them. In the nineteenth century, Charles Darwin (2006, p.837) later summarized the core of this perspective by saying that the "difference in mind" between the "higher animals" and us is to be measured in degree rather than kind. Preceded by evolutionary thinkers like his own grandfather Erasmus Darwin (17311802) and Jean-Baptiste Lamarck (1744-1829), Charles Darwin's perspective was not an entirely new counter to the mechanistic worldview of Descartes, where humans have minds and animals do not and we are fundamentally different from them. The ethological and evolutionary perspective actively developed a pre-existing discourse that saw humans as their own unique form of animal material, not some sort of non-animal set apart from nature - a nature made up of mutually dependent species intertwined in complex cooperation as well as competition.

Like Darwin's description of evolution as the cooperation and competition of plants, birds, insects, and worms inhabiting an entangled bank, there are always many diverse actors in any empire, bringing their own agencies to what is meant to be a unifying and uniform project (Darwin, 2006, p.760; Howe, 2002, p.15, 30). As the healer Martín de Porres incorporated nonhuman animals, their sentience, and their needs into the Spanish imperial project, the scientist Ram Brahma Sanyal did the same for the British empire in Kolkata (then Calcutta). Because of his failing eyesight, Sanyal was forced to leave medical school after three years of training. He went on to apply his mastery of the case study method to work at the Calcutta Zoological Gardens, where he rose through the ranks 
from caretaker to superintendent, with British allies overcoming opposition to an Indian taking a position that was assumed to be "meant for an Englishman." As superintendent, he carefully recorded the behaviors of the animals in his charge, and worked toward enriching their environments and lives (Mittra, 1996). He was fascinated by their behaviors and sympathetic to their needs, although he sometimes failed to identify care that would keep them alive. An orangutan in his care lived only seven years, and in his Hand-book of the management of animals in captivity he noted this animal's susceptibility to "the slightest change in the weather"(Sányál, 1892, p.1). Despite his failure to keep the orangutan alive, Sanyal (1892, p.2) did try to provide enrichment and mental stimulation, arguing:

An orang-outang's dwelling, like a human habitation, requires suitable furniture to make it complete. Perches, swings, trunks of trees, horizontal bars, have been found to be the best substitutes for this creature's natural surroundings. Wooden balls afford it perpetual amusement, and a common looking-glass of ordinary dimensions, firmly fixed to the wall, is an object of the greatest curiosity and pleasure to this wild man of the woods.

Today, along with chimpanzees, orangutans have passed the mirror self-recognition test, indicating some sense of self and embodiment (Matsuzawa, Parr, 2008). A good observer of orangutans, Sanyal still directed a nineteenth-century zoo that confined its animals to cages, rather than placing them in a space that might have real trees. He compromised in the imperial, industrial context in which he found himself, but continued to try to alleviate the restrictions of captivity where he could. The Calcutta Zoological Gardens also seem to have had more success with more familiar animals from the Indian subcontinent; at the time that his Hand-book was published in 1892, a Rhesus monkey "obtained in 1877 is still alive, and in excellent health," as were Indian fruit bats acquired in 1881 (Sányál, 1892, p.23, 112). Meanwhile, a polar bear "merely deposited by a dealer who had sent it to this country for sale" only lived from March 1886 to November 1887, despite Sanyal's efforts to provide ice on a daily basis. He wrote, "A polar bear is one of those animals which should never be acquired for exhibition in this climate," and that "every device that could possibly be adopted to mitigate its sufferings was tried" (p.98). Sanyal apparently worried about sentient beings in his care, even if others thought of them as mere objects to be traded. On India's indigenous Hanuman langurs, he noted:

In keeping these animals it is necessary to bear in mind that hanumans are essentially gregarious animals, and that unless a large number of them are kept together they pine away and die. But to crowd twenty or thirty of them into a comparatively small cage would be equally wrong. Apart from any question of cruelty, it is detrimental to their health to deprive them altogether of the opportunity of indulging the habit of bounding and leaping which they possess in an astonishing degree in a state of freedom (Sányál, 1892, p.12).

Sanyal was a voice for the agency and achievements of Indians subjected to British domination, and for the nonhuman animals who were subjugated as well. He listened to and cared for his zoo animals to the best of his ability and resources, and his skill within the context of his time was recognized with the publication of his Hand-book. Sanyal tried 
to make the Calcutta Zoological Gardens a place to educate humans in the behaviors of living nonhuman animals, rather than a mere display of human dominance over nature. His educational mission countered the objectification of nonhuman animals in slaughterhouses that reduced them to meat for food or laboratories and lecture halls that reduced them to machines for improving human health.

The English word "shambles" originally referred to an open-air slaughterhouse, and in 1903 the Swedish feminists and antivivisectionists Lizzy Lind af Hageby and Leisa Schartau published The shambles of science: extracts from the diary of two students of physiology. These two women opposed vivisection for medical school demonstrations, and enrolled in the London School of Medicine for Women to better argue their position using the scientific language of the day. In February 1903, they witnessed a vivisection performed by physiologist William Bayliss on a terrier-type brown dog. Lind af Hageby and Schartau stated the dog was not adequately anesthetized (as required for vivisection by an 1876 British law), while Bayliss countered that it was. Even though it was later corroborated that the dog had been illegally used in two procedures, which was also against the 1876 law, Bayliss sued for libel and won his case. What appears to have been a very irregular procedure (regardless of whether the dog was adequately anesthetized or not) eventually became a very public cause celèbre. With the participation of feminists and antivivisectionists like Charlotte Despard and individuals representing the Church of England's antivivisectionist movement, 120 pounds were collected to erect a statue commemorating the brown dog in London's working class Battersea district. In November and December of 1907, riots broke out, with medical students in support of vivisection attacking the statue with crowbars and sledgehammers. Women's suffrage meetings were invaded, although not all women seeking the vote were antivivisectionists. Events came to a head when trade unionists and socialists joined antivivisectionists and feminists in defending the statue of the brown dog, with crowds sometimes coming to blows in the streets. When Battersea politics shifted and a local council supporting vivisection was elected, the statue was eventually removed and destroyed in March 1910 (Lansbury, 1985, p.3-25; Kalof, 2007, p.139-140).

The brown dog incident was a rebellion against the inherent effort to dominate humans and nonhumans alike, with scholar Coral Lansbury explicitly arguing that women and workers identified with a dog used and tormented by a dominant male elite. Bayliss's work did lead to gains in knowledge on pancreatic function, and along with his collaborator Ernest Starling he coined the term "hormone" for what they found to be an engine of biochemical function and change (Sir William Bayliss, 1924), but an important question remains (one blatantly posed by Spinoza in the seventeenth century and Bentham in the late eighteenth century): at what cost? Into the twentieth century, many scientists continued to ease their consciences by viewing nonhuman animals as stimulus-response machines, even as Descartes did. Others admitted animal sentience but valued the needs of humanity as hierarchically more important than those of nonhuman animals, following Spinoza. Despite the efforts of nineteenth-century antivivisectionists and vegetarians, and contemporary animal rights activists and vegans, this is where we remain: in a discussion and debate that elaborates on our conflicted views of our status as animals, including the very animal pursuit of hierarchical standing and resources. 
Empire, whether political, economic, or both, is very much about dominating the land and agency of others, and today this includes decimating entire populations of orangutans to produce more palm oil for human use (Beech, 29 June 2019). In the nineteenth century, the specimen collector and naturalist Alfred Russel Wallace came to regret his killing of an orangutan mother as he unsuccessfully tried to raise the surviving orphan. A co-discoverer of evolution via natural selection, he eventually wrote of his opposition to vivisection, sympathy for vegetarianism, and support of women's suffrage (Berry, 2002, p.136-138, 25-26, 350; Smith, 20 Sep. 1905). An outlier in the scientific community compared to the more famous Darwin, Wallace also went to séances and admitted his belief in a deity behind the process of evolution by means of natural selection. A man who rewarded his guide Ali handsomely in material possessions when leaving the Malay Archipelago, Wallace eventually also grew out of his earlier racist sense of European imperial superiority, arguing that he could find his god through the common human moral quest that proved the equality of all peoples, despite European technological advances and imperial dominance (Alves, 2008; Camerini, 2002, p.105). Although he was never a vegetarian himself, Alfred Russel Wallace reflected on multiple trends that countered the quest of a male imperial dominance over women, conquered peoples and nonhuman animals alike. Some voices still speak to this sort of reflection and praxis today, even as there are those who would deforest without end, driving multiple nonhuman species to extinction, despite opposition from some indigenous peoples still trying to follow their traditional ways. Indeed, these indigenous people sometimes pay for these ideals with their lives (Leithead, 24 Feb. 2003; Godin, 29 July 2020). Individual wealth and human comfort take priority for these new economic imperialists, and this pursuit of wealth definitely does not include all people, just as it ignores orangutans and other animals.

\section{The Anthropocene and nonhuman animals today}

With the human population approaching eight billion in 2021, we still have no answer to the question of whether we will live the sympathy of Montaigne, Cavendish and Sanyal, or whether we will use up nonhuman animals, their habitats, and even targeted human groups as resources and objects. When we kill and remove indigenous people from their lands, we exhibit imperialist behavior: the lust to dominate that is also found in ignoring the needs of shrinking wild animal populations to make more room for the cattle we consume (Yale, n.d.). Some will certainly argue that humans must be fed, including with the cheapest meat possible to satisfy vitamin B-12 and iron requirements, but how humane or even rational are we, with global temperatures on the rise and pandemic diseases spreading in response to the way we use the planet and its nonhuman inhabitants? Are we merely like our evolutionary cousins, like chimpanzee communities fighting over a fig or nut tree, while (in our case) the forest is burning around us?

These concerns are expressed today by biologists and natural philosophers Edward O. Wilson and Donna J. Haraway in their reflections on the Anthropocene. Both see a certain horror in the term - the final human imperial statement, placing us in control of 
the entire natural world. Wilson and Haraway challenge us to think of humans as a part of nature, rather than completely apart from and above it. Together with other scientists, Wilson offers a plan to spare half the planet for life other than humanity. This would reserve viable, extant ecosystems in pockets where other animals might still express their sentient behaviors in the habitats that allow them to thrive. Couched as a "goal" (according to Wilson, "People understand and prefer goals" to processes), this half-earth proposal would require a multinational effort to enforce (Wilson, 2016, p.3-4, 229-231). With the Intergovernmental Panel on Climate Change predicting that temperatures will rise 2.5 to 10 degrees Fahrenheit over the next century, glaciers visibly melting at alarming rates, and nation-states failing to meet their 2015 Paris Agreement pledges to reduce emissions, our rational ability to control our own self-destructive behavior is in doubt (Victor et al., 2017; Shaftel et al., n.d.). However, Donna Haraway presents an alternative that allows for our imperial drives. Starting her Staying with the trouble with a reflection on the intelligence and survival of pigeons in our urban human environments, Haraway (2016, p.3-7, 16-29, 102-103) tells us to find and support what nonhuman animals we can in these troubling times - to "make kin" with nonhumans and give them what refuge we can. Haraway admits that there just may be too many humans on this planet foreveryone to live like late twentieth-century citizens of the United States without some form of ecological collapse affecting us, and, to a greater degree, nonhuman animals. If we cannot make kin instead of an overabundance of human babies, we may be doomed to population decline through pandemics, conflict over shrinking resources, and systemic poverty, destroying a number of species as we continue to consume unsustainably in our decline. This will still leave the pigeons and rodents who successfully live with us in our wake, giving the planet another nonhuman chance, just as we mammals took advantage of the dinosaurs' demise, and the evolved children of some dinosaurs survive even today as birds, including pigeons.

Both Wilson and Haraway do not want us to put faith in machines and genetic engineering, in today's Frankensteins and Moreaus. They call upon readers to see if we can still feel for other sentient, nonhuman beings around us, like Montaigne and perhaps even Descartes with his little dog Monsieur Grat. Wilson (1984) has even pointed out that large numbers of us enjoy being around other lifeforms, a sentiment he terms "biophilia." Though he supported vivisection (in a limited and regulated manner) and hunted, Charles Darwin still pampered the pets in his life, including a little fox terrier named Polly who was his companion in old age (Townshend, 2009, p.11, 108). Our feelings for other creatures are visible, and even found in those cruel conquistadores who still mourned dogs like Becerrillo. The question remains whether these feelings for life can be made universal, or whether we can only unite in smaller groups as social animals before a real or perceived enemy. Can we put other animals on the same footing as us humans? Can we even embrace equality for all our conspecifics? This question is older than globalization after 1492, but its urgency accelerated with modern imperial expansion across the globe. This is the too often hidden central theme of the Anthropocene: the human war against nature and nonhuman animals, which thankfully is not accepted by all humans. 


\section{NOTES}

${ }^{1}$ This essay is both an exercise in historical animal studies and the comparative historical study of "empire." For an introduction to this latter subfield, see Stephen Howe's (2002, p.1) brief summary of the topic: "A great deal of the world's history is the history of empires. Indeed it could be said that 'all' history is imperial - or colonial - history, if one takes a broad enough definition and goes far enough back." Howe (2002, p.15) justifies this stance by focusing on a human quest to dominate: "Empires, then, must by definition be big, and they must be composite entities, formed out of previously separate units. Diversity - ethnic, national, cultural, often religious - is their essence. But in many observers' understanding, that cannot be a diversity of equals. If it is, if there is no relation of domination between 'core' and 'periphery', then the system is not an empire but deserves a title such as 'commonwealth'". For a grand overview comparing and contrasting the imperial projects of the Spanish and British in the western hemisphere, see J.H. Elliott's (2006) Empires of the Atlantic World.

${ }^{2}$ Prior to the evolutionary arrival of anatomically modern Homo sapiens some 200,000 to 300,000 years ago (Wood, 2019, p.109), the background rate of extinction known from the fossil record is about one species per million species per year.

${ }^{3}$ In Afro-dog: blackness and the animal question, Bénédicte Boisseron reminds us that any attack on "speciesism" should logically draw comparisons between the human species and other animal species, not between the oppression of some humans ("blacks") and nonhuman animals. Jeremy Bentham (1780, p.309, note a) actually drew that invidious comparison. Just before his show of sympathy for animal sentience and suffering, he compared long-suffering slaves to subjected animals. Boisseron $(2018$, p.14, 20) would have us speak species-to-species and not just compare one group within the human species to nonhuman animals.

\section{REFERENCES}

ACOSTA, José de. Natural and moral history of the Indies. Edited by Jane E. Mangan; translated by Frances M. López-Morillas. Durham: Duke University Press, 2002.

ADAMS, Carol J. The sexual politics of meat: a feminist-vegetarian critical theory. New York: Bloomsbury Academic, 2015.

ALVES, Abel A. The animals of Spain: an introduction to imperial perceptions and human interaction with other animals, 1492-1826. Leiden: Brill, 2011.

ALVES, Abel. Humanity's place in nature, 18631928: horror, curiosity and the expeditions of Huxley, Wallace, Blavatsky and Lovecraft. Theology and Science, v.6, n.1, p.73-88, 2008.

AT LONDON ZOO Homo sapiens is just another primate species. The New York Times, 28 Aug. 2005. Available at: https://www.nytimes. com/2005/08/28/world/europe/at-london-zoohomo-sapiens-is-just-another-primate-species. html. Access on: 3 Oct. 2020.

BEECH, Hannah. One casualty of the palm oil industry: an orangutan mother shot 74 times. The New York Times, 29 June 2019. Available at: https://www.nytimes.com/2019/06/29/world/ asia/orangutan-indonesia-palm-oil.html. Access on: 4 Oct. 2020.

BENTHAM, Jeremy. An introduction to the principles of morals and legislation. London: T. Payne and Son, 1780. Available at: https:// gallica.bnf.fr/ark:/12148/bpt6k93974k/f2.image. Access on: 4 Oct. 2020.
BERRY, Andrew (ed.). Infinite tropics: an Alfred Russel Wallace anthology. London: Verso, 2002.

BEUSTERIEN, John. Transoceanic animals as spectacle in Early Modern Spain. Amsterdam: Amsterdam University Press, 2020.

BEUSTERIEN, John. The armadillo: Spain creates a curious horse to belittle America. Bulletin of Spanish Visual Studies, v.1, n.1, p.27-52, 2017.

BOAS, George. The happy beast in French thought of the seventeenth century. Baltimore: The Johns Hopkins University Press, 1933.

BOISSERON, Bénédicte. Afro-dog: blackness and the animal question. New York: Columbia University Press, 2018.

CAMERINI, Jane R. (ed.). The Alfred Russel Wallace reader: a selection of writings from the field. Baltimore: The Johns Hopkins University Press, 2002.

CAVENDISH, Margaret, Duchess of Newcastle. Poems and fancies with The Animal Parliament. Edited by Brandie R. Siegfried. Toronto: Iter Press; Tempe: Arizona Center for Medieval and Renaissance Studies, 2018.

COWIE, Helen. Exhibiting animals in nineteenthcentury britain: empathy, education, entertainment. Basingstok: Palgrave Macmillan, 2014.

DARWIN, Charles. From so simple a beginning: the four great books of Charles Darwin. Edited by Edward O. Wilson. New York: W.W. Norton, 2006. 
DÍAZ DEL CASTILLO, Bernal. Historia verdadera de la conquista de la Nueva España. Edited by Alonso Remón. Madrid: Imprenta del Reino, 1632. Available at: https:// books.google.com/books?id=LHLF6XIP95 YC\&printsec $=$ frontcover\&source $=$ gbs_ge summary_r\&cad $=0 \mathrm{v}=$ onepage $\& \mathrm{q}=\mathrm{la} \% 20$ rabona\&f=false. Access on: 20 Oct. 2020.

ELLIOTT, John H. Empires of the Atlantic World: Britain and Spain in America, 1492-1830. New Haven: Yale University Press, 2006.

FUNES MONZOTE, Reinaldo. Animal labor and protection in Cuba: changes in relationships with animals in the nineteenth century. In: Few, Martha; Tortorici, Zeb (ed.). Centering animals in Latin American history. Durham: Duke University Press, 2013. p.209-242.

GODIN, Mélissa. Record number of environmental activists killed in 2019. Time, 29 July 2020. Available at: https://time.com/5873137/ record-number-killing-environmentalactivists-2019/. Access on: 10 Oct. 2020.

GROVE, Richard H. Green imperialism: colonial expansion, tropical island edens and the origins of environmentalism. Cambridge: Cambridge University Press, 1995.

HARAWAY, Donna J. Staying with the trouble: making kin in the Chthulucene. Durham: Duke University Press, 2016.

HOAGE, Robert J.; ROSKELL, Anne; MANSOUR, Jane. Menageries and zoos to 1900. In: Hoage, Robert J.; Deiss, William A. (ed.). New worlds, new animals: from menagerie to zoological park in the nineteenth century. Baltimore: The Johns Hopkins University Press, 1996. p.8-18.

HOWE, Stephen. Empire: a very short introduction. Oxford: Oxford University Press, 2002.

KALOF, Linda. Looking at animals in human history. London: Reaktion Books, 2007.

LAMKIN, Megan; MILLER, Arnold I. On the challenge of comparing contemporary and deep-time biological-extinction rates. BioScience, v.66, n.9, p.785-789, 2016.

LANSBURY, Coral. The old brown dog: women, workers, and vivisection in Edwardian England. Madison: The University of Wisconsin Press, 1985.

LEITHEAD, Alastair. Bushmen "moved for diamonds." BBC News, 24 Feb. 2003. Available at: http://news.bbc.co.uk/2/hi/africa/2793779. stm. Access on: 10 Oct. 2020.

LÓPEZ LUJÁN, Leonardo et al. Entering the underworld: animal offerings at the foot of the great temple of Tenochtitlan. In: Arbuckle, Benjamin S.; McCarty, Sue Ann (ed.). Animals and inequality in the Ancient world. Boulder: University Press of Colorado. 2014. p.33-62.

MATSUZAWA, Tetsuro; PARR, Lisa. Selfrecognition of mirror reflection. In: Carta: Center for Academic Research and Training in Anthropogeny. University of California at San Diego, 2008. Available at: https://carta. anthropogeny.org/moca/topics/self-recognitionmirror-reflection. Access on: 4 Oct. 2020.

MITTRA, D.K. Ram Bramha Sanyal and the establishment of the Calcutta Zoological Gardens. In: Hoage, Robert J.; Deiss, William A. (ed.). New worlds, new animals: from menagerie to zoological park in the nineteenth century. Baltimore: The Johns Hopkins University Press, 1996. p.86-93.

MONTAIGNE, Michel de. The complete essays. Translated by M.A. Screech. London: Penguin Books, 1991.

MORE, Thomas. Utopia. Edited by Edward Surtz, S.J. New Haven: Yale University Press, 1964.

MURPHY, Olivia. Guide to the classics: Mary Shelley's 'The last man' is a prophecy of life in a global pandemic. The Conversation, 4 May 2020. Available at: https://theconversation.com/guideto-the-classics-mary-shelleys-the-last-man-is-aprophecy-of-life-in-a-global-pandemic-136963. Access on: 1 Aug. 2020.

MYERS, Kathleen Ann. Fernández de Oviedo's chronicle of America: a new history for a New World. Austin: University of Texas Press, 2007.

NORTON, Marcy. The chicken or the 'iegue': human-animal relationships and the Columbian exchange. The American Historical Review, v.120, n.1, p.28-60, 2015.

OLIVEIRA, Cynthya. Human rights and exhibitions, 1789-1989. Journal of Museum Ethnography, n.29, p.71-94, 2016.

OVIEDO, Gonzalo Fernández de. Historia general y natural de las Indias, islas y tierra-firme del Mar Océano: primera parte. Edited by José Amador de los Ríos. Madrid: Imprenta de la Real Academia de la Historia, 1851. Available at: http://www. cervantesvirtual.com/obra/historia-general-ynatural-de-las-indias-islas-y-tierrafirme-del-maroceano-primera-parte--0/. Access on: 14 Nov. 2020.

OVIEDO, Gonzalo Fernández de. Sumario de la natural historia de las Indias. Toledo: Ramón de Petras, 1526. Available at: http://bdh.bne.es/ bnesearch/detalle/bdh0000050339. Access on: 22 Nov. 2020.

PAGDEN, Anthony. The fall of natural man: the American Indian and the origins of comparative ethnology. Cambridge: Cambridge University Press, 1982. 
PASO Y TRONCOSO, Francisco del (ed.). Papeles de Nueva España. 7v. Madrid: Sucesores de Rivadeneyra, 1905-1906.

REICHENBACH, Herman. A tale of two zoos: the Hamburg Zoological Garden and Carl Hagenbeck's Tierpark. In: Hoage, Robert J.; Deiss, William A. (ed.). New worlds, new animals: from menagerie to zoological park in the nineteenth century. Baltimore: The Johns Hopkins University Press, 1996. p.55-56.

RESTALL, Matthew. When Montezuma met Cortés: the true story of the meeting that changed history. New York: Ecco, 2018.

REUTERS LIFE. Australia zoo puts humans on display. Reuters, 21 Jan. 2007. Available at: https:// www.reuters.com/article/us-australia-zooidUSSP890620070110. Access on: 3 Oct. 2020.

RITVO, Harriet. The animal estate: the English and other creatures in the Victorian Age. Cambridge, MA: Harvard University Press, 1987.

ROBBINS, Louise E. Elephant slaves and pampered parrots: exotic animals in eighteenth-century Paris. Baltimore: The Johns Hopkins University Press, 2002.

ROTHFELS, Nigel. Savages and beasts: the birth of the modern zoo. Baltimore: The Johns Hopkins University Press, 2002.

SAHAGÚN, Bernardino de. Florentine Codex: general history of the things of New Spain. Book 11: earthly things. Translated by Charles E. Dibble and Arthur J.O. Anderson. Santa Fe: The School of American Research; The University of Utah, 1981a.

SAHAGÚN, Bernardino de. Florentine Codex: general history of the things of New Spain. Book 2: the ceremonies. Translated by Charles E. Dibble and Arthur J.O. Anderson. Santa Fe: The School of American Research; The University of Utah, 1981b.

SAHLINS, Peter. 1668: the year of the animal in France. New York: Zone Books, 2017.

SÁNYÁL, Ram Bramha. A hand-book of the management of animals in captivity in Lower Bengal. Calcutta: Bengal Secretariat Press, 1892.

SEWELL, Anna. Black beauty. Edited by Kristen Guest. Peterborough: Broadview, 2016.

SHAFTEL, Holly et al. (ed.). The effects of climate change. NASA: Global Climate Change, vital signs of the planet, n.d. Available at: https://climate.nasa. gov/effects/. Access on: 14 Nov. 2020.

SHELLEY, Mary. Frankenstein. Edited by J. Paul Hunter. New York: W.W. Norton, 2012.
SHELLEY, Mary. The last man. Edited by Morton D. Paley. Oxford: Oxford University Press, 1994.

SIR WILLIAM BAYLISS, F.R.S., Professor of General Physiology, University College, London. The British Medical Journal, v.2, n.3324, p.489-490, 1924.

SMITH, Charles H. (ed.). Dr. Wallace and vivisection (S622a: 1905). The Alfred Russel Wallace page, 20 Sep. 1905. Available at: https:// people.wku.edu/charles.smith/wallace/S622A. htm. Access on: 14 Nov. 2020.

SPANG, Rebecca L. "And they ate the zoo": relating gastronomic exoticism in the siege of Paris. MLN, v.107, n.4, p.752-773, 1992.

SPINOZA, Benedictus de. Ethics. In: Curley, Edwin (Edition and translation). The collected works of Spinoza. Princeton: Princeton University Press, 1985. p.408-617.

TOWNSHEND, Emma. Darwin's dogs: how Darwin's pets helped form a world-changing theory of evolution. London: Frances Lincoln, 2009.

VENTER, Oscar et al. Sixteen years of change in the global terrestrial human footprint and implications for biodiversity conservation. Nature Communications, v.7, n.12558, 2016.

VICTOR, David G. et al. Prove Paris was more than paper promises. Nature, v.548, n.7665, p.25-27, 2017.

VOLTAIRE. Dictionnaire philosophique, portatif. London: 1765. Available at: https://books.google. com/books?id=BpY8AAAAcAAJ\& printsec $=$ frontc over\&source $=$ gbs_ge_summary_r\&cad $=0 \mathrm{v}=$ onep age $\& \mathrm{q} \& \mathrm{f}=$ false. Access on: 15 Oct. 2020.

WAGSCHAL, Steven. Minding animals in the Old and New Worlds: a cognitive historical analysis. Toronto: University of Toronto Press, 2018.

WILSON, Edward O. Half-Earth: our planet's fight for life. New York: Liverlight, 2016.

WILSON, Edward O. Biophilia. Cambridge, MA: Harvard University Press, 1984.

WIMMLER, Jutta. The devil's beatings: African dimensions of early modern demonology in the Atlantic world. Journal of Religion in Africa, v.45, n.3/4, p.249-278, 2015.

WOOD, Bernard. Human evolution: a very short introduction. Oxford: Oxford University Press, 2019.

YALE University. Yale School of the Environment. Cattle ranching in the Amazon region. Global forest atlas, n.d. Available at: https://globalforestatlas.yale.edu/amazon/landuse/cattle-ranching. Access on: 27 Oct. 2020.

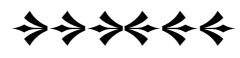

